Review Article

\title{
Higher education and skills development in Africa: An analytical paper on the role of higher learning Institutions on sustainable development
}

\author{
Peter M. F. Mbithi, Judith S. Mbau, Nzioka J. Muthama, Hellen Inyega, Jeremiah M. Kalai \\ University of Nairobi
}

Article history:

Received: 11 August 2021

Accepted: 19 August 2021

Available online: 27 August 2021

\begin{abstract}
A B S T R A C T
Many Higher Education Institutions (HEIs) in Africa face challenges that require the intervention of national governments, development partners and other stakeholders. HEIs also require new investment paradigms to maximize students' acquisition of work-ready skills, knowledge and attitudes to enable students to contribute effectively to the workforce. The objective of this study was to identify reforms and investments needed to strengthen Higher Education (HE) in Africa and to inform the design and implementation of future investments and policy for sustainable development. A systematic review approach, involving a synthesis of literature on this theme in Africa in recent years, by African governments, education networks, academia and international bodies, was employed. The study used data from UNESCO and World Bank databases which were blended with the synthesis of the literature. The obtained literature was analysed and synthesized on the basis of its relevance and value to the HEIs study discourse. Textual and thematic analysis tookcentre stage with a view to establishing current reforms in HEIs and the concomitant investments that national governments and other key stakeholders need to make to have robust HEIs. The study used the Human Capital Theory that postulates that the most efficient path to the national development of any society lies in the improvement of its population, which is considered as the human capital. Despite criticisms of the human capital theory at the individual level on the extent to which education is directly related to improvements in occupation or income, human capital theorists generally assume that after all the known inputs into economic growth have been explained, much of the unexplained residual variance represents the contribution of the improvement of human capital, of which education is seen as most important (Merwe, 2010). The results of the study show that HEIs have done very little to promote Intra-Africa Academic Mobility and nurture HEI-industry partnerships to address demand and supply aspects of the labour force. The massification of higher education, resulting in a democratization of education, and the advent of the knowledge economy and globalization, among other factors, are being experienced without commensurate planning and with no corresponding accompanying increase in resources to enable the HEIs cope with the increased student population. HEIs in Africa are sub-optimally capacitated to combat Africa's pressing challenges such as unemployment, climate change and COVID-19 pandemic. The study points out that HEIs need to evolve in tandem with continental and global market needs to achieve Sustainable Development Goal (SDG) number 4 on quality education. Further, it recommends that HEIs should encourage Intra-Africa Academic Mobility and foster HEI-industry partnerships to address demand-and-supply aspects of the labour force. In this respect, HEIs in Africa should be developing curricula aimed at building capacity of leaders and professionals to respond to the need to decarbonize and dematerialize development in Africa and leverage on the Fourth Industrial Revolution. Consequently, HEIs must prepare students to be entrepreneurial and resilient; able to continue to learn and reinvent themselves and their careers throughout their lives. Indeed, HEIs should view themselves as creative hubs where partners come together and harness each other's synergy to innovate and solve societal problems.
\end{abstract}

Higher education,

Sustainable development, learning centres that include universities, colleges, professional schools (that provide preparation in such fields as

Higher-Educational Institutions (HEIs) are tertiary-level 
engineering, law, theology, medicine, business, music, and art) as well as teacher-training schools, junior colleges, and institutes of technology. African governments, regional economic organizations and civil society organizations have in the last couple of decades increasingly recognized the need to reshape Higher Education (HE) to meet the ever-changing skills needs in Africa. Higher education is vital in the implementation of the 2030 Agenda for Sustainable Development, particularly, Sustainable Development Goal (SDG) 4 on quality education; SDG 5 on gender equality; SDG 8 on decent work and economic growth; SDG 9 on industry innovation and infrastructure; and SDG 10 on reduced inequalities.

Viewed this way, HE is an indispensable form of investment in human capital, as a high level or specialized form of human capital whose contribution to economic growth is indispensable (AfDB, 2020; Fonn et al., 2018; Tilak, 2017; World Bank, 2017). Education for Sustainable Development is recognized as an integral part of Sustainable Development Goal (SDG) 4 on quality education and a key enabler of all other SDGs. Against this backdrop, several factual and strategic issues affecting HE have been identified and are summarized herein. The issues constitute the structure and context of subsequent sections of this paper.

The HE sector is generally characterized by low spending efficiency. African governments spend about 5\% of GDP on education, which is the second highest percentage in any region in the world. The region has the worst education spending efficiency, although African countries devote significant resources to education. According to the AfDB's African Economic Outlook (2020) report, Africa has a 58\% efficiency score for primary education and $41 \%$ efficiency for secondary education, both more than 20 percentage points lower than the second-worst performing region in the world.

Sub-optimal infrastructure is a setback that deserves urgent examination. Infrastructure deficiency of HE institutions is an almost insurmountable challenge in Sub-Saharan Africa (SSA) (Abugre, 2018; Fonn et al., 2018). Infrastructure deficiencies have been estimated to account for $30-60 \%$ of the negative effects on the productivity of African HEIs.

Growth in enrolment, coupled with representation of women, is still insufficient to meet a rising demand for HE, and the pressure on SSA countries to further expand access to HE is increasing. Access to higher education for the relevant age group remains at $5 \%$, the lowest regional average in the world, just one-fifth of the global average of about $25 \%$. The continent has few scientists and engineers, with the share of students enrolled in engineering, manufacturing, and construction ranging from as low as 3\% in Burundi to only $12.8 \%$ in Morocco, compared with at least $20 \%$ in Austria, Germany, Malaysia, and Mexico. Women are underrepresented in higher education, in particular in the fields of science and technology (Fonn et al., 2018).

Poor research and innovation remain a barrier to the competitiveness of African HEIs. In the past, Africa was unable to benefit from and capitalize on the opportunities brought about by industrial revolutions (AUDA-NEPAD, 2019). This inability weakened its position in relation to international competitors. In light of the benefits and challenges posed by the Fourth Industrial Revolution (4IR), Africa cannot afford to, nor does it have to, miss out on the innovative opportunities brought about by the 4IR especially because of the disruptive nature of emerging technologies coupled with the current COVID-19 and post-COVID-19 pandemic eras.

In view of the foregoing, the state of policy and practice in HE, and its connection to skills development, are interrogated. The subsequent implications on the SDG 4 on quality education; SDG 5 on gender equality; SDG 8 on decent work and economic growth; SDG 9 on industry innovation and infrastructure; SDG 10 on reduced inequalities, and SDG 13 on combating climate change, are evaluated. Further, an appraisal is made of how academic policies and practices are integrated in HEIs for improved quality and relevance of Higher education. They are the subject of the subsequent sections.

\section{State of Higher Education Policy and Practice and its Linkage to Skills Development in Africa}

\subsection{Skills Demand and Supply}

Skills development is the process that identifies skill gaps and develops and hones skills. Several key issues are pertinent in regard to HE skills development in Africa. The enrolment and growth of HEIs in Africa remains low. In the last twenty years, HE enrolment worldwide almost doubled, going from 19\% to 38\% between 2000 and 2018. Africa continues to lag behind, with $9 \%$ in access to higher education, having grown from $4 \%$ in 2000 , compared to the $77 \%$ of the higher income sector (UNESCO, 2020). Access to tertiary education in sub-Saharan Africa (SSA) doubled between 2000 and 2018, but the enrolment rate remained low at $9 \%$ in 2018, about a quarter of the global average, the lowest regional average in the world. The growth has been insufficient to match the rising demand driven by an improved access to primary and secondary education, a growing young population, and employment shifting away from agriculture to manufacturing and services (Gandhi, 2018; Reddy et al., 2016). The region faces several challenges in its HE systems. For many countries in the region, it is extremely difficult to secure adequate funding for tertiary education and thus costs for tertiary education are high. At the same time, growth in enrolment remains insufficient to meet a rising demand for tertiary education, yet pressure on SSA countries to expand access to tertiary education has intensified over time. Further, the region has remained as one of the regions where women's enrolment continues to lag behind men's enrolment in tertiary education.

Internationalization and modernization remain under-articulated. A modernization in HE is a process of socio-cultural transformation involving values, norms, institutions, and 
structures that include glocalization, global competition, branding and ranking, and institutional autonomy and academic freedom. Disruption occasioned by global mega issues (such as the rising role of technology, climate change, demographic shifts, urbanization, and globalization of value chains) are changing the nature of work and skills demands. Yet, HEIs are not producing students with requisite cognitive, socio-emotional, technical and digital skills for the 21st century labour market (Williamson \& Hogan, 2020). The major challenge facing HEIs remains the mismatch between skills produced and industry needs.

The massification of HE (a global phenomenon, resulting in democratization of education, the advent of the knowledge economy and globalization has not been commensurate with planning and accompanying increase in resources to enable HEIs to cope with the increased student population. Mass enrolment of students in universities has thus outstripped HEIs' resources. Glocalization is not fully realized to widen access, globalise HE and equip graduates with 21st Century employability skills. HEIs in SSA have achieved minimally in research and innovation, in part due to underfunding, compared to their global counterparts who have more direct relationships with industry. Brain drain of HE faculty is an endemic problem in Ethiopia as in other African HEIs like Ghana where academic staff is inadequate (Abugre, 2014).

Equitable access, retention and completion remain inadequate in many HEIs. Many students who manage to enrol in education or training programmes do not complete their studies and miss out on obtaining formal qualifications, which can dramatically reduce the return on educational investments in terms of lifetime earning potential (Arias et al., 2019; Ndaruhutse \& Thompson, 2016). Future proofing efforts and mitigation strategies against learning losses occasioned by pandemics such as the COVID-19 in many HEIs are low. Many HEIs are not inclusive and responsive to the needs of all learners and educators. Inno $\neg$ vative catchup strategies to meet diverse learning needs and provide alter $\neg$ nate pathways for engaging or reengaging the most marginalized, especially girls and learners with disabilities, are inadequate.

Student engagement, mobility and employability are inadequately addressed. Occupational mobility and portability of qualifications from one HEI to another HEI within and across African countries remain low. Employability of HEI graduates remains equally low due to several factors such as skills mismatch and low levels of literacy. For instance, of the entire working-age population more than $80 \%$ in Ghana and more than $60 \%$ in Kenya cannot infer simple information from relatively easy texts (World Bank, 2018). Such young people cannot compete in the wage job market even though there is a shortage of wage jobs on offer. Educated urban youth thus crowd into self-employment. Not surprisingly, $30 \%$ of youth with at least a secondary education report being over-skilled for their jobs. This amplifies the poten- tially limited absorptive capacity of African labour markets (AfDB, 2020). Skills production does not match labour market demand or development needs (American Council of Trustees and Alumni Institute for Effective Governance, 2015; Fonn et al., 2018; Mba, 2017). Further, inequality in academic mobility is prevalent in African HEIs consequently undermining research and innovation of HEIs in Africa. To enhance student employability there is need for curriculum reforms to ensure alignment with industry demands.

Governance and leadership, focused on skills development, presents two factors: Firstly, the skills regulation ecosystem remains rigid in many African countries, reducing mobility and making it difficult for workers to find jobs and for firms to find the right workers. Secondly, skills development initiatives are uncoordinated and disjointed across HEIs within a country and across Africa, resulting in duplication of efforts, wastage of resources and minimal impact of HE programmes. Further, there is limited inter-HEI coordination of skills development.

Overall, the aforementioned issues put the realisation of SDG 4 in jeopardy. By the year 2030, SDG 4 targets to ensure equal access for all women and men to affordable and quality technical, vocational and tertiary education, including university.

\subsection{Higher Education Leadership and Governance}

Several HE leadership and governance issues may be discerned from the current policy and practice on the continent. Governance structures in many HEIs are generally weak, unreliable or ineffective, or both unreliable and ineffective (Abugre, 2018; Varghese, 2016; CODESRIA, 2017). This negatively affects SDG 4 on quality education; SDG 8 on decent work and economic growth; SDG 9 on industry innovation and infrastructure. Abugre singles out deficient institutional policies, deficient infrastructure, unbalanced students' numbers versus teaching loads, human resource deficits, research quality challenges and bureaucratic and/ or inconsistent administrative environment. Aburge (2018) claims that governmental policies thwart HEIs' efforts to initiate major changes or enact long-term policies beneficial to the HEIs' development without political authorization.

Incentives are too weak to support platforms for innovation and entrepreneurship development. Instead, the incentives stifle creativity and change in HEIs (Vuong et al., 2017). Bureaucracy and administrative inertia affect service delivery. In this connection, for instance, excessive delays in the acquisition of teaching and research materials, long holdup in the hiring of academic staff and complicated, inconsistent and non-uniform promotion systems for academic staff (exacerbated by a lack of clear-cut procedures to guide academic promotions) negatively affect the performance of the HEIs. At the same time, recruitment into African universities is limited and may become even narrower than it is currently (Abugre, 2018; Gasu, 2018). 
University education as a private good: The current governance system of HEIs is marked by a departure from the public good notion to a new conception that university education is a private good as any other commodity in the marketplace for potential consumers. With a change in the philosophy that had driven HE in the past, there has been a corresponding universal shift in the tenets that underpinned HE governance from the traditional collegial system to managerialism. It has become necessary for HE leadership in Africa to realign its institutional goals to meet commercial interests in public service delivery. The global drive to redefine the essence of higher education has sparked debates regarding whether leadership of African universities has the capacity to manage the consequences of managerialism in a competitive global context.

Public universities, public funding, and government control characterized the governance and management of HE during the period following independence. Not until the last decade of the 20th century, university governance was mostly influenced by the traditional understanding that HE was a public good with socially beneficial returns (Mosweunyane, 2013; OECD, 2012). The governance cultures and the goals which institutional leadership pursued were understood to be in line with the public good philosophy. Through the instrumentality of neoliberal ideology now awash in the African political economy, however, the philosophy of HE as a public good is fading (World Bank, 2019).

Transitioning from traditional governance to corporate managerialism and academic quality: Transformations in the notions of public management and the corresponding governance systems that come with it have engendered splits within the academic community about how to run public universities. In the traditional governance arrangement, HE leadership was largely absolved from the stress of finding alternative sources of funding for its institutions, as the state was supposed to deliver on its funding obligations. Nonetheless, since the last decade of the 20th century, the HE landscape has witnessed massive transformations, caused by such factors as globalisation, internationalisation, privatisation, state downscaling and managerialism. These developments have had significant consequences on HE governance, as there has emerged downscaling of state funding and a new demand on the leadership of public universities to corporatize its operations. Public universities are to make up for the shortfall in their funding from alternative sources, as the social contractual obligation on the state as the exclusive funder of public universities has changed. The liberalisation wave of the HE sector has brought into being many private academic service providers from in-country and offshore sources. The change from the collegial systems to managerial arrangements has posed new challenges to leadership of these institutions in meeting their mandates as the universities take on a posture of capitalist corporate entrepreneur. The shifts are essentially the products of the neoliberal revolution that has undercut prior notions of the state's responsibility towards HE. The prior notions of HE as a public good, and its graduates as being a social good, have been questioned by the advocates of neoliberalism.

Liberalization and commercialization: The liberalization and commercialization experience has thrown up new challenges to the HE leadership in Africa. How this situation bodes for the role of HE in the national development agenda cannot be ignored. The liberalization wave is being pushed further around the carousel of globalization and internationalization of HE and raised many questions as to whether the national agendas for higher education in Africa are not being hijacked by the very forces that have caused its underdevelopment. Indeed liberalization, commercialisation and managerism cumulatively act as a barrier in achieving SDG 10 on reduced inequalities; SDG 8 on decent work and economic growth; and SDG 9 on industry innovation and infrastructure.

\subsection{Financing of Higher Education}

The landscape of HE funding in Africa has been rough for many years. HEIs globally, even in the developed world, face fiscal problems. The degree of these problems is, however, far greater in Africa than anywhere else. In Sub-Saharan Africa, HEIs are the most financially challenged in the world (World Bank, 2019). The main funders of education are governments, households, and development partners. Globally, real spending on education has grown steadily over the last 10 years with governments contributing the largest share of the expenditure (Fig. 1 and Fig. 2). However, government education spending in Africa, as a share of GDP has remained flat in the past 10 years, as represented in Fig. 1 and Fig. 2 by low-income country (LIC) and lower-middle-income country (LMIC) curves. In SSA countries, funding of the HE subsector is a critical issue due to inadequate and unsustainable financing sources and mechanisms (Mgaiwa, 2018). Empirical evidence shows that the economic inability in most African countries has been the stumbling block to adequate funding for HE (Tilak, 2015). Such a scenario is unlikely to propel Africa achieve the development of HE in line with its expectations, with a negative impact on SDG 4 on quality education.

There has been an acute cut in HE budgets in recent years globally despite its higher return on investment. In Africa, the allocated funding in relation to requests or demand is decreasing and creating a mismatch between student enrolment and budgetary allocations. The sources of funds to finance education at any level in most countries, both developed and developing, are determined by the tax base, political systems, and policy principles for financing education. Given the importance of $\mathrm{HE}$ in research and its impact on social, economic, and technological development, HE needs to be at the government's top priorities in budgeting and fund disbursement. 
Government, household and official development assistance spending on education, constant 2018 US dollars (trillions), 2009-2019

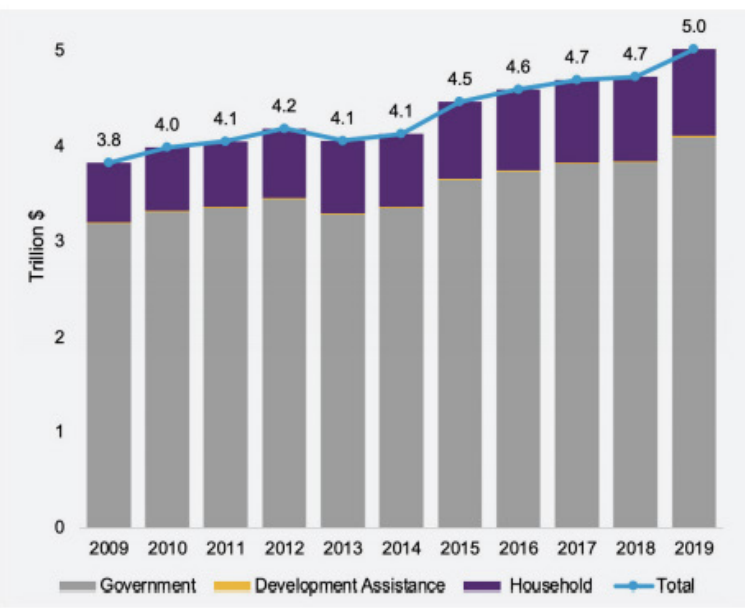

Growth in real education spending, by income level (2009=100)

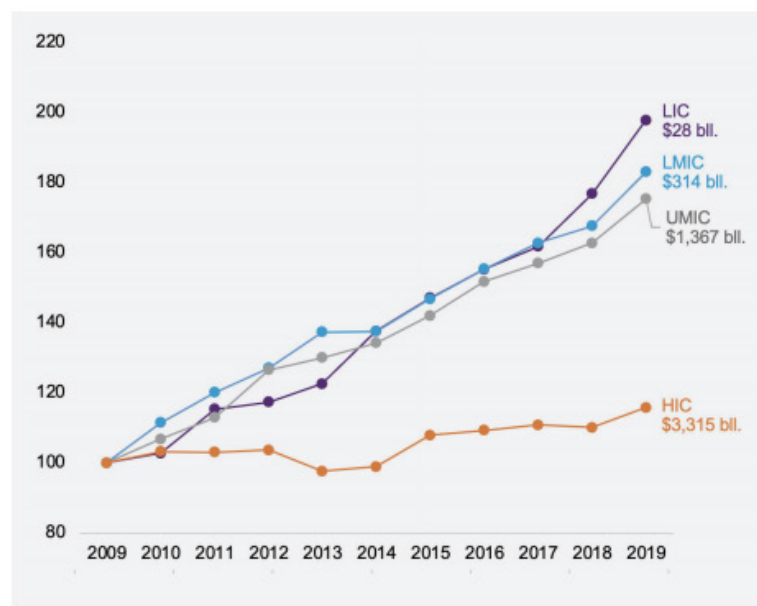

Fig. 1. Real spending on Education in the last 10 years

Source: World Bank - Education Finance Watch 2021 using data from OECD, UIS, IMF and World Bank online databases. Note: World Bank income group classifications in 2020 are used to group countries: LIC = low-income country, LMIC = lower-middle-income country, UMIC = upper-middle-income country, and HIC = high-income country.

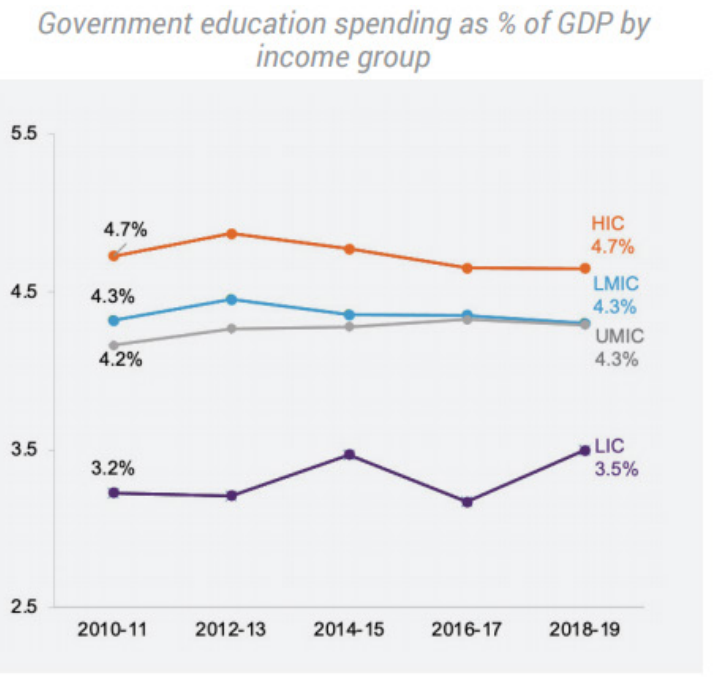

\section{Total public education spending per capita (constant 2018 US dollars)}

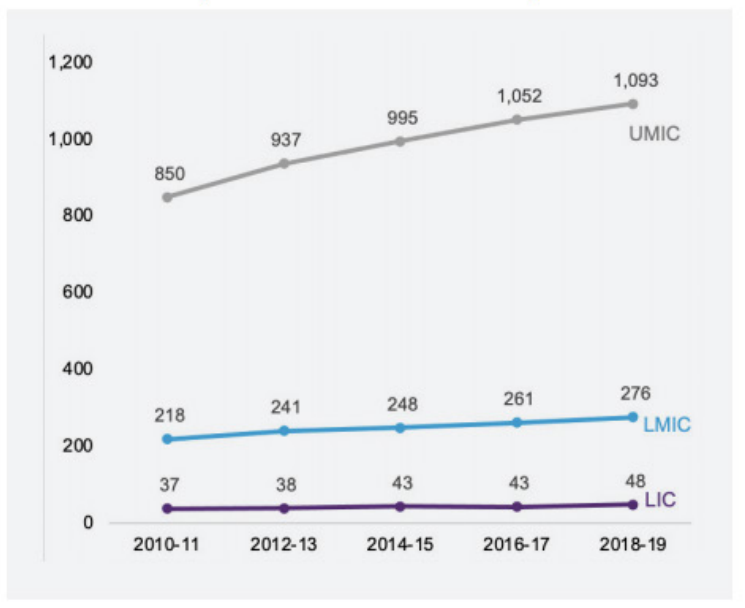

Source: EFW team estimates using data from OECD, UIS, IMF and World Bank online databases.

Fig. 2. Public Spending per Capita

To have sustainable and reliable sources of funds, public $\mathrm{HE}$ institutions need to find ways to diversify their income streams so as to reduce their dependence on public funds, which are often tied to economic and political factors such as through grants and contracts, alumni contributions, and partnerships with corporate organizations. The funding challenge has been made complex by the COVID-19, which poses a new dimension in country budget allocations to financing education. In responding to the COVID-19 crisis, learning institutions have had to incur additional spending for compliance with the necessary measures to control contagion and fund programmes to make up for the losses in learning. Despite the urgent need for adequate funding to allow learning institutions to reopen safely, about $50 \%$ of the learning institutions cut their education budgets (Table 1). This scarcely bodes well for the future, when macroeconomic conditions are expected to worsen. It is foreseen that lower-income countries are more likely to see a decreasing trend in their education budgets or to shift from a positive to a negative trend after the COVID-19.

\subsection{Commercialization and Privatization of Higher Edu- cation: The Response to the COVID-19}

Across the globe, there is a pressing need to support the freedom of HE workers and their right to participate in the formulation and implementation of institutional policies, collective agreements and regulatory frameworks around teaching and learning. This need includes educational tech- 
nologies (edtechs) and its impact on academic freedom, decent work, quality education as well as data governance and privacy. In this context, commercialization and privatiza- tion comes to the fore (Williamson \& Hogan, 2020).

Privatization and commercialization are two distinct but often related phenomena in the provision of public services.

Table 1: Change in Education Budgets after the COVID-19 by Earlier Status (\%)

\begin{tabular}{llccc}
\hline & & All countries & $\begin{array}{c}\text { High and upper } \\
\text { middle-income }\end{array}$ & $\begin{array}{c}\text { Lower and lower } \\
\text { middle-income }\end{array}$ \\
\hline Countries with decreasing budgets & Decreased post-COVID-19 & 24 & 8 & 35 \\
pre-COVID-19 & Increased post-COVID-19 & 21 & 33 & 12 \\
Countries with increasing budgets & Decreased post-COVID-19 & 28 & 25 & 29 \\
pre-COVID-19 & Increased post-COVID-19 & 28 & 33 & 24 \\
\hline & Total & 100 & 100 & 100 \\
\hline
\end{tabular}

Source: Tanaka (2020)

Hogan and Thompson (2017) suggested that privatization happens to HEIs through the development of quasi-markets through institutional policy and structures such as state-regulated private sector participation in HEIs. Commercialization occurs in HEIs and involves the creation, marketing and sale of educational goods and services for commercial gain. The global response to COVID-19 shows the overlapping nature of privatization and commercialization. On the one hand, privatization is apparent as a "policy tool" that is reflecting and responding to a rapid shift in the modality of schooling. Public-private partnerships and commercial contracts are being formulated as part of a deliberate government strategy to use the private sector to help move learning online in response to the COVID-19 crisis. On the other hand, commercialization is about how actors profit from the "commodification" of education. Interestingly, commercialization is simultaneously prolific and hidden in our mapping of the global response to COVID-19. The sheer scale of products and services on offer to HEIs to assist with online learning attests to this. Even though many of these products and services are being offered "free" for a limited time, it would be perceived that this social response is a key feature of "disaster capitalism" and evidence of how "pandemic politics" is beginning to affect practices of learning, with the global education industry likely capitalizing on an avenue of future profitability (Williamson \& Hogan, 2020).

COVID-19 pandemic has been used as an exceptional opportunity for expanding privatization and commercialization in $H E$, particularly through the promotion of edtech as short-term solutions to campus closures and the positioning of private sector actors as catalysts and engineers of post-pandemic HE reform and transformation. This is argued on the premise that emergencies produce catalytic opportunities for market-oriented privatization policies and commercial reforms in education. Indeed, pandemic privatization and commercialization of HE during the COVID-19 emergency is a multi-sector process involving diverse actors that cut across government, business, consultancy, finance, and international govern- ance, with transnational reach and various effects across geographical, social, political, and economic contexts. All this illustrates how "disaster techno-capitalism" has sought to exploit the pandemic for private sector and commercial advantage. This is a space to watch and take advantage of in Africa.

Diverse organizations from multiple sectors translated the public health crisis into an opportunity to reimagine HE for the long term as a digitally innovative and data intensive sector of post-pandemic societies and economies. Face-to-face teaching constituted an urgent global public health threat, but it was perceived by organizations including education technology businesses, consultancies, international bodies and investors as a longer-term problem and threat to student "up-skilling," "employability," and global post-COVID-19 economic recovery. Framed as a form of "emergency relief" during campus closures, education technologies were presented as an opportunity for investment and profit-making, with the growing market of edtech framed as a catalytic enabler of the long term (Williamson \& Hogan, 2020). On the other hand, COVID-19 pandemic has exposed and perpetuated digital inequality in higher education in Africa.

\subsection{Competitiveness of Higher Education Institutions}

The status of the competitiveness of African HEIs is examined using four leading HE global ranking bodies: Webometrics, uniRank, QS World University Ranking, and Times Higher Education. According to their databases, there are about 1,225 officially recognized HEIs in Africa in 2021, which is only $8.9 \%$ of 13,723 HEIs worldwide. The estimated population of the African continent is around $16.1 \%$ of the total world population, implying that the African HE system and offerings are underrepresented in the world at least in terms of the number of HEIs.

The Ranking Web or Webometrics is an academic ranking of HEIs which uses both webometric (all missions) and bibliometric (research mission) indicators. These indicators include Visibility—web contents impact number of exter- 
nal networks [subnets] linking to the institution's webpages) - and Transparency-top-cited researchers (number of citations from Top 210 authors and excellence or scholar) number of papers amongst the top $10 \%$ most cited in each one of all the 27 disciplines of the full database.

The 2021 Webometrics world university ranking shows that eight of the ten top universities in Africa are in South Africa. The remaining two are in Egypt. It is noteworthy that the top university in Africa is number 216 globally; it is not surprisingly, therefore, that many African HEIs actually function on the periphery of the international scientific community and are unable to participate in the production and the adaptation of knowledge to successfully address domestic economic and social problems. Quality, relevance, and flexibility of academic programmes remain a challenge. Ranking and visibility of African HEIs remain poor and present huge investment opportunities to contribute to improved rankings.

UniRank: Out of 1,225 recognized HEIs in Africa included in the uniRank database,586 are public (that is, officially affiliated to or run by national, state or local governments) and 601 are private (Table 2). The type of control of the remaining 38 African universities included in the uniRank database is unknown. In terms of the number of public versus private universities, the uniRank database shows a strong balance between public and private HE in the African continent as a whole. According to the uniRank, 164 out of the top 200 universities in Africa (82\%) are public HEIs. Differences and peculiarities may exist in each African country's HE system, but, generally, the majority of African public HEIs are not-for-profit organisations, not necessarily in legal terms but certainly in terms of nature and institutional purposes such as role, scope and mission.

The QS World University Ranking's methodological framework is compiled using six simple metrics: Academic Reputation (40\%), Employer Reputation (10\%), Faculty/Student Ratio (20\%), Citations per Faculty (20\%), International Faculty Ratio and International Student Ratio (5\% each).
The Times Higher Education World University Ranking focuses on judging research-intensive universities across the universities core mandates in: teaching, research, research influence, international outlook and knowledge transfer. The Rankings use indicators grouped into five areas: Teaching (the learning environment), Research (volume, income and reputation), Citations (research influence), International Outlook (staff, students and research) and Industry Income (knowledge transfer).

Methodologies used by ranking bodies are interrogated to tease out salient issues of importance to African HEIs. The uniRank includes HEIs worldwide which are officially recognized, licensed and/or accredited by national or regional bodies such as ministries of higher education or government-recognized accrediting organizations, which are officially licensed or authorized to grant at least fouryear undergraduate degrees (bachelor's degrees) and/or postgraduate degrees (master's and doctoral degrees) and which provide HE courses mainly in a traditional face-toface learning format delivered through on-site facilities.

Challenges for the competitiveness of the HE system in Africa are discernible. To date, a very small percentage of African universities has featured in these global rankings. The reasons for this are diverse and complex. One clear contributing factor are the HEIs' diverse priorities when compared to global elite research universities. According to the four ranking systems the main issues of the HE systems in Africa are inadequate funding, low research output and innovation (but for very few exceptions), lack of harmonization of the HE systems in the African continent as a whole, and HEIs' global low reputation among academics and prospective employers. Many African HEIs face challenges that require the intervention of like-minded stakeholders collaborating with national governments and development partners to ensure students graduate with requisite skills to contribute meaningfully to the workforce. These challenges are a pointer to the risk of not attaining SD4 on quality educations, SDG 9 on industry innovation and infrastructure, and ; SDG

Table 2: Ranking Data of HEIs in Africa Based on Four Leading Global Ranking Systems in 2021

\begin{tabular}{lccc}
\hline Name of website & $\begin{array}{c}\text { No. of universities in } \\
\text { Africa }\end{array}$ & $\begin{array}{c}\text { No. of public } \\
\text { universities }\end{array}$ & $\begin{array}{c}\text { No. of private } \\
\text { universities } \\
\text { all over the world }\end{array}$ \\
\hline UniRank & 1225 & 586 & 601 \\
Webometrics & 1917 & - & - \\
QS World University ranking & 11 & - & - \\
\hline Times Higher Education Ranking & 27 & - & - \\
\hline
\end{tabular}

8 on decent work and economic growth.

Several HEIs invest in academic research to build up their profiles, but not much is invested in marketing and/or mining the research to better understand the needs and wants of their "special customers" and the influencing roles of par- ents in HEIs. Besides traditional research approaches, there is need to invest in marketing managers. In this way, the use of modern research techniques, such as marketing analytics will help research on prospective students' expectations ( Mogaji et al., 2020). 


\subsection{Role of Higher Education Institutions in Socio-Eco- nomic Development}

Any strong economy in the world today is built with the support of education (Mgaiwa, 2018). Higher education is the primary mechanism for promoting economic growth, contributes significantly in shaping social values of nations and is instrumental in fostering growth, reducing poverty and boosting shared prosperity. It benefits the individual and the entire educational system. The key for success in a globalized world lies increasingly in how effectively a country can assimilate the available knowledge and build comparative advantages in areas with good growth prospects and in how a country can use technology to address the most pressing environmental challenges.

HEIs and more so universities produce new knowledge through research that is needed to address societal challenges while promoting development. HE is a determinant as well as the outcome of income and economic benefits for public and private good (Abugre, 2018). Development is driven by the sum total of the skills, knowledge and experience that a society possesses-globally and locally (glocalization). Higher-level institutions in SSA that are equipped to impart quality education and conduct relevant applied research can play a critical role in producing workers with skills to assimilate technology and make effective decisions that help industry to diversify into a broader range of products as well as in stimulating innovations. All this underscores the role of HEIs in equipping graduates with 21st-century employability skills (World Economic Forum, 2017) (Fig. 3). Strengthening industry-academia collaboration is central to this process, however.

Universities operate in local, national, regional, and international contexts and need to acknowledge political realities, community expectations, and their own espoused values. The current pattern of skills production in Africa does not match labour market demand or development needs as seen in their level of preparedness to tap into the opportunities presented by the 4IR (Fig. 4 and Fig. 5).

Africa's level of preparedness to take up five key 4IR technologies is moderate to low as presented in Fig. 4. This situation has been occasioned by inadequate digital strategies, low levels of education and skills of employees.

Inadequate investment in education has meant that African HEIs are currently incapable of responding to immediate skill needs or supporting sustained productivity-led growth in the medium term (Mba, 2017). This may hinder achievement of SDG 8 on decent work and economic growth and SDG 9 on industry innovation and infrastructure.

\section{Integrating Academic Policy and Practice to Improve the Quality and Relevance of Higher Education}

In an endeavour to salvage the realisation of SGD 4 on quality of education and consequently SDG 8 on decent work and economic growth in Africa, there is need to im-

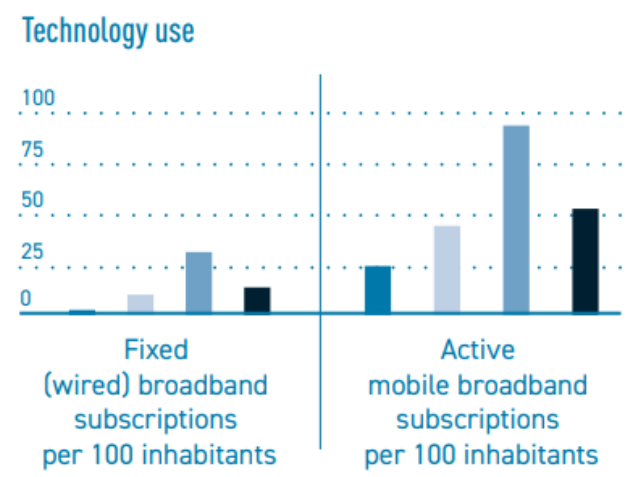

per 100 inhabitants

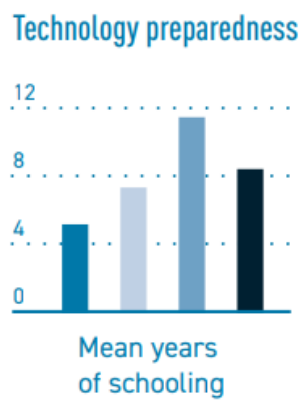

per 100 inhabitants

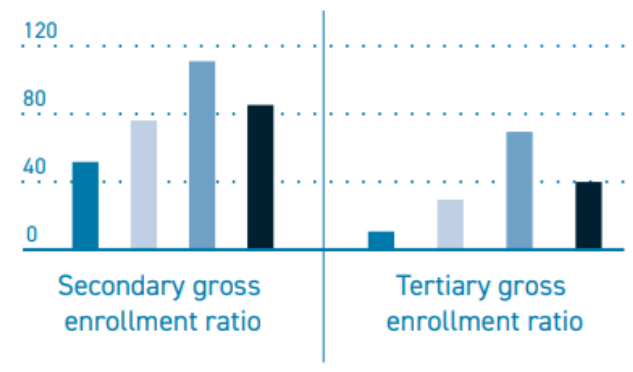

B Africa Growth Initiative

Africa

All developing countries

Developed countries

World ational Success

(2019) and International Telecommunication Union, Measuring the Information Society Report Volume 1 (Geneva: International Telecommunication Union, 2018).

Fig. 3. Status of Africa for technology access, use and preparedness in readiness for the 4IR

prove quality and relevance of HE through integration of policy and practise. This calls for innovative reforms in governance and leadership of in HEIs.

\subsection{Governance Reforms of HEIs}

HEIs' proof of the value of HE and generation of student return on investment are not apparent and should be made manifest (Kristin Blagg and Erica Blom, 2018). HEI leaders need to offer more clarity on what degrees they offer and demonstrate the relevance of the skills sets in the global and the local economy. HEIs should cultivate critical thinking, aliveness and creativity, which move students beyond content into memorable learning experiences. HEIs must analyse megatrends shaping the future of global higher education, use labour market intelligence and balance agility and consistency in how the HEIs plan, innovate and execute their 


\section{Firms' preparedness for the Fourth Industrial Revolution}

The majority of African firms report moderate to very low levels of business preparedness for five key 4IR technologies. Notably, firms are least prepared for artificial intelligence/robotics and blockchain technologies. Experts say that the low levels of preparedness stem from the inability of firm leadership to develop effective digital strategies, as well as low levels of education and skills of employees.

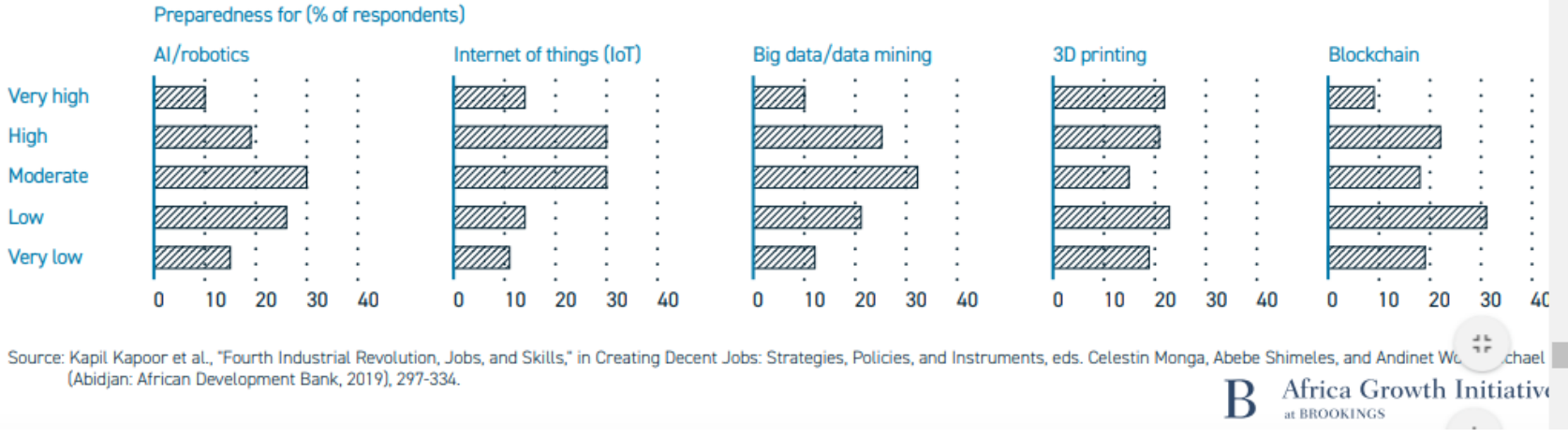

Fig. 4. African Firms Level of Preparedness in readiness for 4IR Technologies

higher education strategies.

HEIs can contribute to establishing Research and Labour Market Information Systems (RELAMIS) in anticipation of skills demand to provide reliable and realistic assessment of economic trends and labour market needs. The system can forecast future demand and guide HEIs accordingly in preparing a constant flow of skilled workforce. Data can be disaggregated by gender to enable interventions to maintain equity and access to HEIs. The RELAMIS will improve relevance and reduce skill mismatch of HEIs in the labour market.

There are several studies and actions related to HEIs on issues about green economy, decarbonisation and conservation as drivers to sustainable natural resource management and resultant creation of jobs (Burns et al., 2018; Harmsen et al., 2021; Muthama, 2019; Scarff Seatter \& Ceulemans, 2017). HEIs in Africa need to do more and spearhead efforts to decarbonize development in Africa. This can be done through sustainable alternative pathways to reach carbon neutrality by the end of the 21st century, by for instance firmly anchoring their programming on the High $5 \mathrm{~s}$ towards green growth: Light up and Power Africa, Feed Africa, Industrialize Africa, Integrate Africa, and Improve the Quality of Life for the People of Africa.

The decolonization and the indigenization of higher education call for an interrogation of education programmes, operations, research and community outreach agenda within their socio-economic environments to ensure that they do not perpetuate or privilege certain ways of thinking and knowing over others, and thus contribute to unsustainable resource use and environmental degradation. Deliberate efforts can be made to decentre the academy as the primary site of knowledge production and dissemination to make way for community engagement and land-based research practices (that is, through participatory research).
Decolonial indigenization requires that universities work to recognize, respect, and support academic processes and redistribute intellectual privilege, while working toward collaborative relationships that decentralize administrative power. Instructional focus goes beyond the what to the why of education to help students to gain knowledge and discover the joy and the beauty of applying that knowledge above and beyond themselves. HEIs must prepare students to be entrepreneurial and resilient, with the ability to continue to learn and reinvent themselves and their careers throughout their lives. Thus, HEIs must evolve in tandem with market needs.

HEIs should align education and jobs not only regionally but also internationally. The HEIs should encourage Intra-Africa Academic Mobility among students and staff and forge HEI-industry partnerships to address demand-and-supply aspects of the labour force. HEIs should morph into creative hubs that attract diverse partners and harness synergies to innovate and solve societal problems and have sustainable impact and thus sustainable development.

The HEI organizational performance should be reformed through systemic changes in practice. A systemic leadership philosophy in HE should be recast towards altruism that espouses inclusivity, equity and justice for all that are undergirded by integrity, social responsibility, transparency and accountability. Such leadership has insight into HE systems, regardless of their complexity, as well as into coalition-building, advocacy tactics and collaborative skills. In essence, systemic leadership could thus be deem to operate at a higher and more complex pedestal than transformative leadership.

As HEIs innovate, they should analyse several scenarios towards world-classiness; local marketization; internationalization of their programmes; education exportation within the broader framework of global entrepreneurship and in- 
dustrialization of HE; investment in infrastructure that supports the digital economy, diversification of funding streams to include more domestic sources; and data and evidence on labour market information towards demand-driven skills system. The HEIs should undertake regular labour market surveys to produce up-to-date information on the status of Human Resource and Development (HRD) in their countries and/or support research and development programmes that transfer knowledge and technology for sustainable development.

\subsection{Re-Thinking Leadership Philosophy of Higher Educa- tion Institutions}

A fundamental question globally is whether higher education serves social, political and cultural purposes, is a central institution of democracy, or is to be perceived, more instrumentally, as an engine for producing measurable learning performance and associated workforce productivity gains (White, 2019). The answer to this question most certainly will drive African HE policy and practice in the coming decade.

Higher education, a viable gateway to African renaissance, must identify multiple and flexible learning and career progression pathways to a sustainable future tailored to learners' unique needs and circumstances and the labour market. Investment in a high-quality workforce can create a virtuous cycle where relevant and quality skills enable productivity growth and foreign direct investment, which result in more and better jobs for the current workforce and more public and private investment in the education and training system. It has multiple benefits of contributing to the attainment of SDG 4 on quality education and SDG 8 on decent work and economic growth. This, in turn, increases employability and productivity for the current and the future workforce.

Higher education leadership philosophy should be recast towards altruism, which involves the unselfish concern for others; doing things simply out of a desire to help, and not because one feels obligated to do so out of duty, loyalty or religious reasons (Mallén et al., 2015). An effective altruism in HEIs espouses inclusivity, equity and justice for all, does "good better" and puts a human face to university leadership as it dismantles bureaucracies that disenfranchise HEI community members. In the lecture room, it can be demonstrated by teaching the why as much as the what of education to help students not only to gain knowledge but also to discover the joy and the beauty of applying that knowledge above and beyond themselves.

Visionary leadership and a sense of urgency are essential to drive the change needed in HEIs. Veney and Sugimoto opine that innovative organizational practices have the greatest effect on performance when they are implemented in concert with one another and are well aligned to achieve organizational goals. Thus, improving organizational performance requires systemic changes in practice. Tuition rates continue to skyrocket while countries spend less on HE than their original projections, resulting in budget cuts across HEall the while when tuition fees in many HEIs have become increasingly beyond the reach of most youth. Worse still, budgetary allocation to universities is likely to shrink even further in the foreseeable future. In Kenya, for instance, the government slashed funding to its public universities by US $\$ 400$ million (a 26\% reduction) in the 2020/2021 financial year (Nganga, 2020). Nganga reported that Universities would get US $\$ 1.13$ billion, down from the US\$1.53 billion, which the government had planned to spend on the institutions earlier in the year as a cost-cutting drive attributed to the coronavirus crisis, that is significantly hurting revenue collections and reducing economic activity.

In view of this reality, HEIs become the new altruism battleground. Altruistic HEI leaders are at their wits' end to find alternative streams of funding (including bursary schemes and scholarships) to support core HEI functions and needy but bright students through their education. The leaders may opt to get into strategic partnerships with philanthropic organizations to fund programmes targeting vulnerable and marginalized populations or people living in conflict and crisis-prone environments. Consequently, social responsibility becomes a hallmark of altruistic HEI leaders who may innovate and ensure that their corporate social responsibility dockets are vibrant and make a real difference for the neediest students. In the process, HEIs can leverage alumni to sponsor specific activities or engage in strategic public-private partnerships to secure additional funding.

\subsection{New Business Model of HEIs - the Triple Helix Model}

Grey matter is a country's main resource, and knowledge has become a key driver of competitiveness. Knowledge produces growth. HEIs can rely on an eclectic mix of business models to inform their programming and forge cross-sectoral relations with like-minded players. Informed by the Helix Model while downplaying its limitations, progressive HEIs can forge mutually beneficial, tripartite, evolving strategic partnerships with a government and industry to foster a country's sustainable economic and social development and contribute meaningfully to a knowledge-based economy (Fig. 5). While governments can, and do, formulate relevant policies and provide finance, innovation support and advisory services to HEIs, HEIs can undertake research and development activities and host technology transfer offices and test centres, and industry can engage in entrepreneurial venturing and product and service development. 


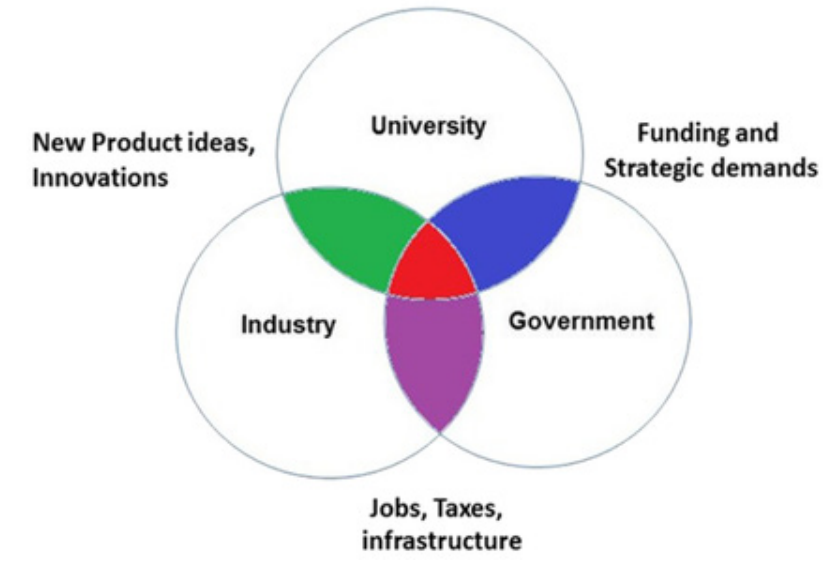

Fig. 5. Triple Helix Strategic Interaction

Apart from the triple helix model, there are many models such as the strategic leadership style. This paper however isolates Systematic Leadership (SL) model based on its key tenet to inform an inward look at one's leadership strengths. Through the use of self-analysis tools such as the styles inventory, the SL model holds out promise for transformative altruistic leadership. The following are key components of the SL model.

Systematic HEI leaders envision, clearly imagine or mentally see a future state. They see existing ideas and imagine ways to creatively or innovatively make the idea better or use them in different ways. Systematic HEI leaders both need to involve or engage the interests, emotions and commitment of all members in their teams or organizations and to value team members' time, talent, ideas, and resources towards achievement of their HEI's vision and mission. Further, systematic HEI leaders secure members' commitment and intentionally invite them into conversations and involve them in decision-making, for to such leaders every opinion counts. Such leaders who see African students being globally competitive will motivate students accordingly.

Systematic HEI leaders need to develop or bring out the capabilities and possibilities of others, as they teach, coach, mentor and advise others. They must consciously find ways to help others embrace new ideas, learn new skills, and stretch themselves to new possibilities. Such leaders are need for the realisation of Africa's Agenda 2063. Systematic HEI leaders plan or strategically design or formulate steps and procedures or map to reach a desired vision or outcome. They act or exert energy towards an outcome. They move forward on an idea to actualise it. They need to be proactive in taking initiatives to launch an idea as well as operate within different systems to steer their institution to great heights. They need to establish strategic internal and external partnerships using their collaborative leadership skills, coalition-building and advocacy tactics and complex systems' insights as shown in Fig. 6. HEI systems should hire systematic leaders as a strategic move to ensure their institutions are globally competitive, successful and resilient. This would then pave way for the realisation of SDG 4 on quality education, SDG 8 on decent work and economic growth in Africa, and SDG 5 on gender equality.

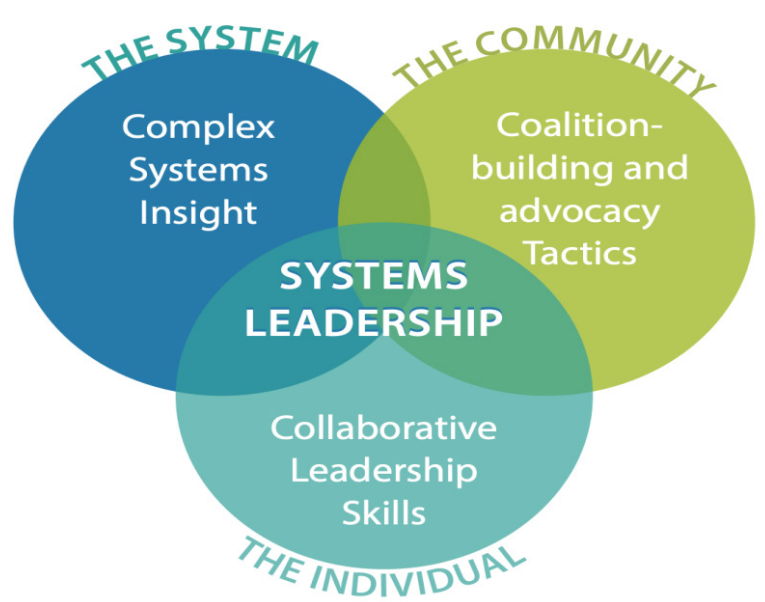

Fig. 6. Key Elements of Systematic Leadership

Harnessing the right human resource follows a process of inception, development, motivation and maintenance. Inception involves strategic human resource planning to recruit and select the best fit for an HEI. Once an employee is presented to the institution, the employee undertakes development activities that include training, capacity building and provision of opportunities for career development. Motivating the employee may include a provision of rewards, awards and recognition as well as adequate compensation, discipline and counselling. In terms of maintenance, motivation may involve a provision of a robust health insurance and workplace safety as well as regular communication.

In a given HEI, faculty and staff must share in the vision and the core values of an institution. Information about the HEI can be provided in different formats such as through emails, trainings, notices, banners and brochures. More comprehensive training must be provided to retain employees and increase productivity as shown in Fig. 7.

In terms of inputs, a human resource team should ensure that faculty, staff and students understand organizational dimensions (such as the culture of learning and commitment to improving performance) and how the dimensions relate to human resource development capacity (such as leadership and professionalism). In terms of processes within the organizational context, faculty, staff and students should be made to understand about strategic relationships and build trust. They should be guided on the relationship between systems and processes and their contribution to creation of a high performance work system and culture as well as the system of accountability. The human resource team must help faculty, staff and students understand the outcomes the institution seeks to achieve.

The human resource team can scan the context within which an HEI operates. In the face of labour market shifts and the rise of automation, HEIs can work collaboratively to 
change education models to models that promote the ideals an HEI espouses.

Higher education leaders need to rethink the purpose of education to adequately prepare students for the future world of work. HEIs need to prepare students to be entrepreneurial and resilient. This is a route towards attainment of SDG 8 on quality of work and economic growth. On their part, students should be equipped with learning to acquire skills to continue learning and reinventing themselves and their careers throughout their lives. All this means that HEIs should evolve in tandem with market needs (Fig. 7) and provide life-long, life-wide and life-deep learning for all learners ( Bélanger, 2016).

New human resource models ensure the growing disconnect between employer demands and college experience are addressed. HEI leaders can devise creative approaches that give students lifelong learning skills that are valuable in the long term. Indeed, lifetime education can be effective in tackling the skills mismatch between what employers say they want and what HE delivers.

Global HEI network will likely be the new normal where institutions partner in sophisticated ways to bring value to one another. New business models in human resources, of necessity, must entail augmenting education-business through strategic collaborations, which may include cross-border partnerships and transnational education or capacity-building models. HEIs may partner with businesses and industry to help students and faculty apply their skills in the workplace. In that way, both parties not only gain but also bring down the cost of education. At the same time, curricula can be tailored to align more closely to needs of the job market and sustainability (Scarff Seatter \& Ceulemans, 2017). Indeed, internalization of education can be an invaluable outcome of strategic collaborations.

From demographic trends, large cities continue to grow as centres of jobs and careers. HEIs should be able to adapt quickly to these needs and align education and jobs regionally and internationally. At the same time, they should forge HEI-industry partnerships to address demand-and-supply aspects of the workforce.

HEIs have a potential to be a creative hub, where partners come together and harness each other's synergy to innovate and solve societal problems through research, innovation, and entrepreneurship. In this respect, HEIs will need to adopt a mind-set that views 4IR-related technology disruption as an opportunity to innovate if they are keen to build on their visions, missions and core values. Technology disruption here refers to the introduction of a new or existing technology that is used and/or created in manner that the incumbent is rendered outdated, over a period of months, years or decades. Winner HEIs will most likely be those that are best at partnering. In any case, each HEI should ensure they are the preferred partner of choice in a rapidly changing world. New emphases on human resource in HEIs will ensure they not only are locally grounded but also are globally connected with technology to enhance linkages and networks.

Rising incomes in developing countries, an important prerequisite to demands for educational opportunities, mean that institutions have new opportunities for innovative educational business models to address the growth in demand. New education models may include new delivery modes such as blended learning and flipped classrooms undergirded by relevant pedagogy, andragogy and heutagogy (Heick, 2015) tailored to students' unique needs.

HEIs will make strategic decisions to become more distinctive in their academic mission so that student choice is informed with real clarity about what that an institution offers. In addition, HEIs need to participate in university rankings, which are the most globally prominent ways to judge institutional reputation -overall.

\subsection{The Role of Higher Education Institutions and AfDB in Africa's Transformation Agenda}

The Pan African vision of "an integrated, prosperous and peaceful Africa, driven by its own citizens and representing a dynamic force in the international arena" is driven by the confidence that, Africa has the capacity to realize her full potential in development, culture and peace and to establish flourishing, inclusive and prosperous societies. Africa is committed towards achieving her aspirations. The aspirations are tightly dependent on the capacity of Africa to produce the skill set needed to drive sustainable development and maintain a peaceful environment-a skill set that is both globalized and glocalized in application and takes cognizant of the fact that Africa needs to capitalize on her demographic dividend. Africa has the largest concentration of young people in the world. The continent's youthful population presents an opportunity for accelerated economic growth and innovation. The youth aged below 35years form about three quarters of African populations. In addition, the share of Africa's youth in the world is projected to increase to $42 \%$ by 2030 and is expected to continue to grow throughout the remainder of the 21st century, more than doubling from current levels by 2055. While Africa's demographic structure offers immense opportunities for a demographic dividend, it poses risks as well, such as underemployment or a lack of unemployment and educational opportunities (UN Population Division, 2015).

HEIs can play a crucial role in addressing these challenges through effective training so that graduates have the capacity to embrace technological advancements required to spur development. Central to this process is concrete government and development partners support to HEIs. Subsequently, well-structured linkage with industry to promote a transfer of skills that are not only relevant but also demand-driven can be achieved. HEIs in African however face some big challenges despite the gradual increase in the number of students enrolled for tertiary education Fig. 8. 


\section{ORGANIZATIONAL CONTEXT}

\section{STRATEGIC HRD GOALS \& OBJECTIVES}

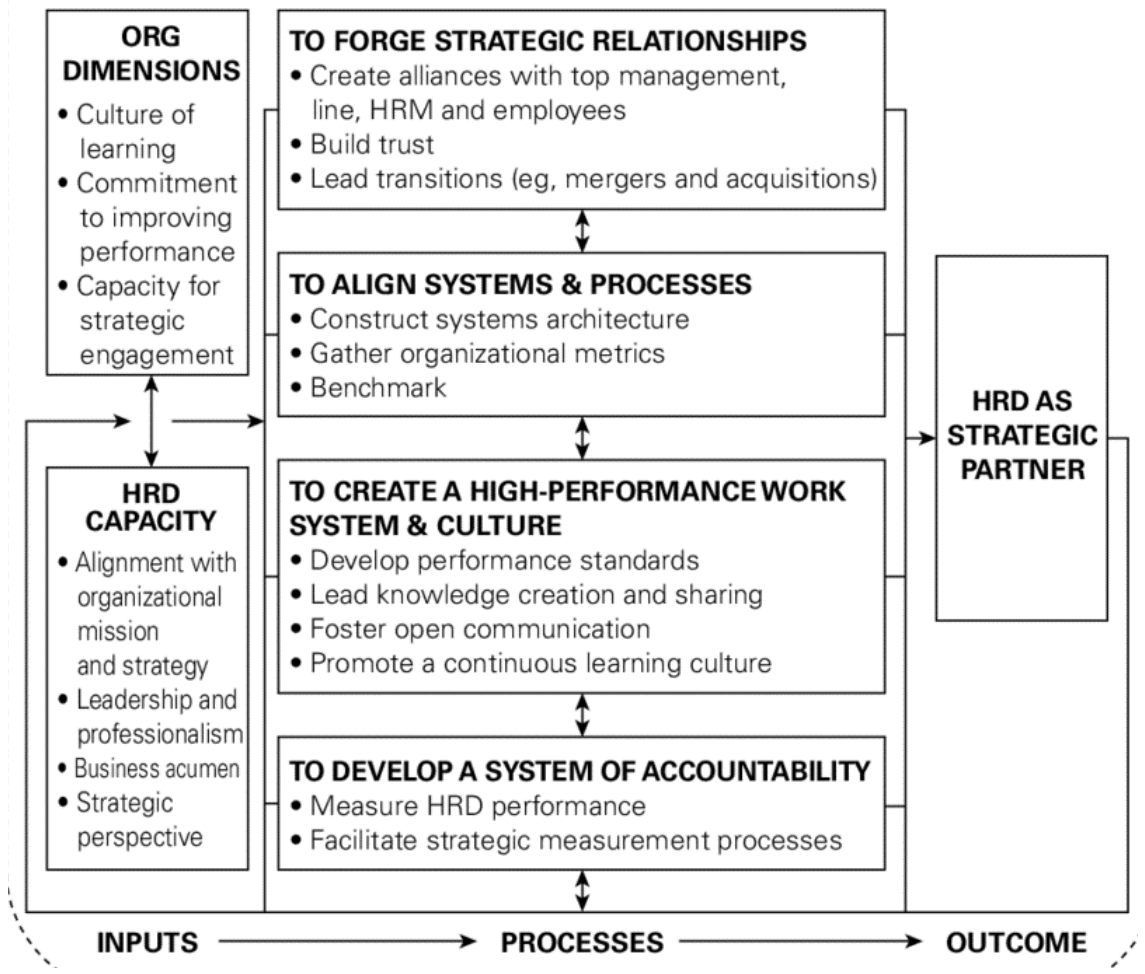

Fig. 7. Strategies for Harnessing Human Resources

HEIs offer Africa an opportunity to tap into its capacity to produce enough skilled work force to spur social, economic and environmental aspects of sustainable development.

In line with Agenda 2063, Africa aspires for development that is people driven. Thus, home-grown financial mechanisms are key in financing HEIs in Africa (African Union Commission, 2015). The transformation Africa seeks for is deeply entwined with the objectives of the AfDB strategy 2013-2022, that aims to improve the quality of the con- tinent's growth by focusing on the High 5s: Light up and Power Africa; Feed Africa; Industrialize Africa; Integrate Africa; and Improve the Quality of Life for the People of Africa. The High 5 s reflect inclusive growth and a transition to green growth, aspects that are central to transforming the lives of the African people while achieving sustainable development. Therefore, HEIs could play the central role in networking with key stakeholders to address the High $5 \mathrm{~s}$ and Agenda 2063. This will be realised as concerted efforts

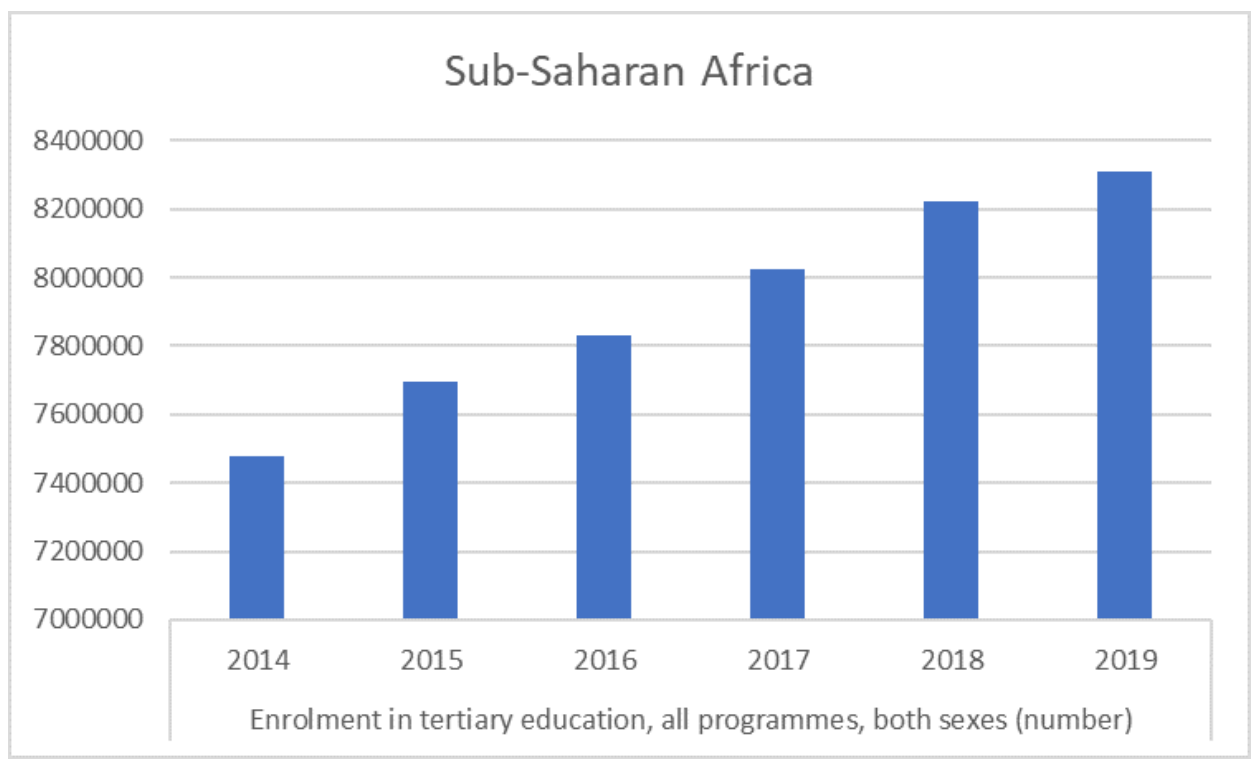

Fig. 8. Gross Enrolment in Tertiary Education in SSA

Source, author. Data retrieved from UNESCO Institute for Statistics (UIS) databank 
by governments and development partners strategically support HEIs to implement measures that will ensure access to higher education for all in line SDG 4.

\section{Conclusion and Recommendations}

The trends synthesized in the previous sections, in the context of the attainment of SDG 4 in Africa, bring following issues to the fore:

The employability of HEI graduates is low due to several factors such as skills mismatch and HEIs infrastructure. Infrastructure in HE is relatively sub-optimal and generally falls short of international standards. Engagement of students in skill development initiatives in the workplace-such as apprenticeships; internships; indentured learnerships; attachments; volunteerships and in-service training-is limited. The skills regulation ecosystem remains rigid in many African countries, reducing mobility and making it difficult for workers to find jobs - and for firms to find the right workers. Skills development initiatives are uncoordinated and disjointed across HEIs within a country and across Africa, resulting in a duplication of efforts, wastage of resources and minimal impact of the programmes. There is limited inter-HEI coordination of skills development. An accurate prediction of specific skills needs key by key thematic cross-cutting themes across the continent. Skills production does not match labour market demand or development needs. These issues need to be addressed for Africa to achieve SDG 4 on quality education and SGD 8 on decent work and economic growth.

High female attrition rates are undermining the potential impact of increased female enrolment. This is a threat to the attainment of SDG 5 on gender equality. The massification of higher education has led to increased opportunities for marginalized, and that universities and HE systems have implemented interventions such as affirmative action policies and targeted financial aid to improve gender diversity although these have not gone uncontested. Attrition rates among women however remain extremely high and Africa has the lowest female enrolment rate overall globally. This issue begs for greater inclusion of females in higher education.

Challenges in HE leadership and governance are contributing immensely to weak competitiveness of African HEIs. These further undermine the realisation of SDG 4 on quality education by 2030. A transformation of HE leadership and governance is critical. To adapt to continually changing HE sector needs, universities must adopt an organizational learning leadership style that encourages experiment and change and rewards the relevance of teaching and learning. The rapidly evolving challenges of the productive sectors and exponential changes in technology mean that universities must be able to continually learn about changing sec- tor needs and adapt teaching and research accordingly. To this end, an adoption of altruistic leadership philosophy and the triple helix and systemic models will prove beneficial in achieving SDG 4 on quality education.

Low research and innovation reputation is notable, to the detriment of SDG 9 on industry innovation and infrastructure. The staff incentive and support system is not conducive to maintaining a long-term team of senior researchers in universities. Generally, there needs to be efforts to support staff both in developing curricula that meet needs of the broader society and in building research capacity. Further, there is a need for stronger incentives and support systems to build strong research teams and portfolios involving industry players. This would include the necessary HEIs' infrastructure and, in turn, trigger and grow innovations.

Most of the HEIs collaboration arrangements in Africa are somewhat ad-hoc and not institutionalized. There are strong financial, technical and human capital related rationale for a collaboration between HEIs. This arrangement hinders opportunities for more systematic cooperation that could be supported by continental and sub-continental network organizations and undermines SDG 10 on reduced inequalities. Collaboration between universities in the Africa region is a much under-utilized opportunity to build the region's collective capacity for higher education. African HEIs can enhance their collaboration with stakeholders. In addition, there is need for engagement with other stakeholders in industry, international development and civil to galvanize complementary resources and increase impact. Further, efforts should be made to enhance mutually beneficial global partnerships and internationalization for resource mobilization and access of research infrastructure to support research and innovation at African institutions.

Africa's level of preparedness to take up five key 4IR technologies is low-negatively impacting on the achievement of SDG 9 on industry innovation and infrastructure African HEIs should see this as an opportunity to design curricula geared towards addressing the skill needs presented by 4IR. The disruptive nature of 4IR technologies may take a toll on many African HEIs if strategies to mitigate against such setback are not formulated. HE leadership may leverage on the current COVID-19 to make relevant inroads. Finally, it is recommended that a roundtable discussion, organised by ESDA, with policymakers and Vice chancellors to communicate this new knowledge products would be timely.

\section{Acknowledgements}

This work was done under the auspices of Education for Sustainable Development in Africa (ESDA) phase 2 project supported by the African Development Bank (AfDB). We thank these institutions for their critical role in this study. A number of experts from ESDA Universities also played a 
part and we are grateful to them. They contributed in the paper review and we single them out, with much gratitude, within their respective Universities: Dr Gyekye Awere from University of Ghana, Ghana; Prof. Samuel Donkoh from University for Development Studies, Ghana; Prof. Olanrewaju Olaniyan from University of Ibadan, Nigeria; Prof. Jennnifer Broadhurst from University of Cape Town, South Africa; Dr Jewette Masinja from University of Zambia, Zambia; Dr John Muriuki from Kenyatta University, Kenya; Dr. Boniface Wambua from University of Nairobi, Kenya; and Dr Farai Kapfudzaruwa from University of Pretoria.

\section{References}

Abugre, J. B. (2018). Institutional governance and management systems in Sub-Saharan Africa higher education: Developments and challenges in a Ghanaian Research University. Higher Education, 75(2), 323-339. https:// doi.org/10.1007/s10734-017-0141-1

AfDB. (2020). African economic outlook 2020: Supplement amid cocvid-19. Africa Development Bank.

African Union Commission. (2015). Agenda 2063: The Africa we want. African Union Commission.

Alex van der Merwe (2010). Does Human Capital Theory Explain the Value of Higher Education? A South African Case Study, Durban University of Technology, South Africa in American Journal of Business Education - January 2010 Volume 3, Number 1 107. http://dx.doi.org/10.19030/ajbe.v3i1.378

American Council of Trustees and Alumni Institute for Effective Governance (ACTA, 2015). Bold leadership, real reform best practices in University Governance. Washington DC: ACTA

Arias, O., Evans, D. K., \& Santos, I. (2019). The skills balancing act in Sub-Saharan Africa: Investing in skills for productivity, inclusivity, and adaptability. World Bank.

\section{AUDA-NEPAD. (2019). African Innovation Outlook III 2019. AUDA-NEPAD.}

Bélanger, P. (2016). Self-construction and Social Transformation: Lifelong, Lifewide and Life-deep Learning. UIL: Les Presses de 1 'Université de Montréal. Google scholar

Bernarda Zamora (2020). A new discussion of the Human capital theory in the methodology of scientific research programmes. WP-AD 2007-26. Google scholar

Burns, H., Kelley, S. S., \& Spalding, H. (2018). Teaching Sustainability: Recommendations for Best Pedagogical Practices. 19, 16. Google scholar

CODESRIA (2017). Higher Education Leadership and Governance in the Development of the Creative and Cultural Industries in Kenya. Dakar: Council for the Development of Social Science Research in Africa. Google scholar

Mallén, F., Chiva, R., Alegre, J. and Guinot, J. (2015), "Are altruistic leaders worthy? The role of organizational learning capability", International Journal of Manpower, Vol. 36 No. 3, pp. 271-295. https://doi.org/10.1108/IJM09-2013-0212

Fonn, S., Ayiro, L. P., Cotton, P., Habib, A., Mbithi, P. M. F., Mtenje, A., Nawangwe, B., Ogunbodede, E. O., Olayinka, I., Golooba-Mutebi, F., \& Ezeh, A. (2018). Repositioning Africa in global knowledge production. The Lancet, 392(10153), 1163-1166. https://doi.org/10.1016/S0140-6736 (18)31068-7

Findler, F., Schönherr, N., Lozano, R., Reider, D. and Martinuzzi, A. (2019). The impacts of higher education institutions on sustainable development: A review and conceptualization. International Journal of Sustainability in Higher Education, Vol. 20 No. 1, pp. 23-38. https://doi.org/10.1108/ IJSHE-07-2017-0114

Gandhi, D. (2018, January). Africa in Focus: Figures of the Week: Higher education enrollment grows in sub-Saharan Africa along with disparities in enrollment by income.

Gasu, J. (2018). Strengthening higher education leadership in Africa: A study of Ghana's situation. Council for the Development of Social Science Research in Africa Avenue (Codesria). Google scholar

Mazon, G., Pereira Ribeiro, J.M., Montenegro de Lima, C.R., Castro, B.C.G. and Guerra, J.B.S.O.d.A. (2020). The promotion of sustainable development in higher education institutions: top-down bottom-up or neither? International Journal of Sustainability in Higher Education, Vol. 21 No. 7, pp. 14291450. https://doi.org/10.1108/IJSHE-02-2020-0061

Harmsen, H., Wang'ondu, V. W., Mbau, J. S., \& Muthama, N. J. (2021). Randomized hotspot strategy is effective in countering bushmeat poaching by snaring. Biological Conservation, 253, 108909. https://doi.org/10.1016/j. biocon.2020.108909

Heick, T. (2015). The Difference Between Pedagogy, Andragogy, And Heutagogy. Retrieved on 5th May, 2021. Google scholar

Hilary I. Okagbue, Abiodun A. Opanuga, Pelumi E. Oguntunde, Patience I. Adamu, Chukwuemeka O. Iroham and Angie O.I. Adebayo (2018). Research Output Analysis for Universities of Technology in Nigeria. International Journal of Education and Information Technologies volume 12, Pp. 105-109). Google scholar

Hogan, A., \& Thompson, G. (2017, December 19). Commercialization in Education. Oxford Research Encyclopedia of Education. https://doi. org/10.1093/acrefore/9780190264093.013.180

Issa, S., \& David, K. (2012). The Challenges of Leadership and Governance in Africa. International Journal of Academic Research in Business and Social Sciences, 2(9), 18. Google scholar

Jaana Puukka (2008), "Mobilising higher education for sustainable development - lessons learnt from the OECD study". Proceedings of the 4th International Barcelona Conference on Higher Education, Vol. 7. Higher education for sustainable development. Google scholar

Kristin Blagg and Erica Blom (2018). Evaluating the Return on Investment in Higher Education: An Assessment of Individual- and State-Level Returns: Education Policy Programme. Urban Institute. Google scholar

Kwiek, M. (2018). Private Higher Education in Developed Countries. In Encyclopedia of International Higher Education Systems and Institutions (pp. 1-9). Springer Netherlands. https://doi.org/10.1007/978-94-017-95531 $92-1$

Mba. (2017, May). Challenges and prospects of Africa's higher education.

Mgaiwa, S. J. (2018). The Paradox of Financing Public Higher Education in Tanzania and the Fate of Quality Education: The Experience of Selected Universities. https://doi.org/10.1177/2158244018771729

Mogaji, E., Maringe, F., \& Hinson, R. E. (Eds.). (2020). Strategic Marketing of Higher Education in Africa (1st ed.). Routledge. https://doi. org/10.4324/9780429320934

Moses Oketch (2016). Financing higher education in sub-Saharan Africa: some reflections and implications for sustainable development. High Educ (2016) 72:525-539 https://doi.org/10.1007/s10734-016-0044-6

Mosweunyane, D. (2013). The African Educational Evolution: From Traditional Training to Formal Education. Higher Education Studies, 3(4), p50. https://doi.org/10.5539/hes.v3n4p50

Muthama, N. J. (2019). Sub-National policy Readiness as Regards the Planet's Carrying Capacity and Environmental Sustainability in Kenya. 1(1), 6. https://doi.org/10.53537/jsep.2019.02.002

Ndaruhutse, S., \& Thompson, S. (2016). Literature review: Higher education and development (p. 31). Commissioned by Norad for Norhed conference on Knowledge for Development. Google scholar

Nganga, G. (2020). Government cuts universities budget by $26 \%$. University World News: Africa Edition. Retrieved on 5th May, 2021

OECD. (2012). Skills Development Pathways in Asia.

Reddy, V., Bhorat, H., Powell, M., Visser, M., \& Arends, F. (2016). SKILLS SUPPLY AND DEMAND IN SOUTH AFRICA. LMIP Publication, Human Sciences Research Council, Pretoria., 108. Google scholar

Vuong, T., Hoyt, L., Rowe, A. N and Carrier, C. (2017). Faculty Perspectives on Rewards and Incentives for Community-engaged Work A multinational exploratory study. Gateways: International Journal of Community Research and Engagement Vol 10, Pp. 249-264. http://dx.doi.org/10.5130/ijcre. v10i0.5268

Scarff Seatter, C., \& Ceulemans, K. (2017). Teaching Sustainability in High- 
er Education: Pedagogical Styles that Make a Difference. Canadian Journal of Higher Education, 47(2), 47-70. https://doi.org/10.47678/cjhe. v47i2.186284

Tilak, J. B. G. (2017). Higher Education, Public Good and Markets (1st ed.). Routledge India. https://doi.org/10.4324/9781315146386

UN Population Division. (2015). Youth population trends and sustainable development.

UNESCO. (2020). Towards universal access to higher education: International trends.

Varghese, N. V. (2016). Governance reforms in higher education: A study of selected countries in Africa. International Institute for Educational Planning (IIEP) 7-9 rue Eugène Delacroix, 75116 Paris, France.

White, E. W. (2019). Leadership in Higher Education: Insights from Academic Advisers. The Mentor: Innovative Scholarship on Academic Advising Volume 21 (2019), 1-10. https://doi.org/10.18113/P8mj2161110 http://www.iiep.unesco.org/sites/default/files/governance_reforms_in_he paper_pf.pdf

Williamson, B., \& Hogan, A. (2020). Commercialisation and privatisation in/ of education in the context of COVID-19. Education international.

World Bank. (2017). Higher Education for Development: An Evaluation of the World Bank Group's Support.

World Bank. (2018). Kenya poverty and gender assessment 2015/16: Reflecting on a decade of progress and the road ahead. Washington, D.C.: World Bank.

World Bank. (2019). Strengthening Agricultural Higher Education in Africa. World Economic Forum. (2017). The Future of Jobs and Skills in Africa-Preparing the Region for the Fourth Industrial Revolution. 